word inflammation the meaning which all pathologists attached to it.

Dr. Olliffe, in reply, referred to the postmortem examinations in M. Bouillaud's hospital, to corroborate his statements with reference to the seat of rheumatism. He also challenged Mr. Bennet to produce a single case of suppuration in that malady.

Dr. M'Moran agreed with Mr. Bennet in his observations on the inflammatory nature of gout, or, at least, of its local manifestation. It was too evident to be denied. He was by no means prepared to admit that the absence of suppuration in gout, even if satisfactorily demonstrated, proved its non-inflammatory nature. $\mathrm{He}$ also considered $\mathrm{Dr}$. Olliffe's views on the neuralgic character of muscular rheumatism as erroneous.

Dr. Dovglas expressed surprise at the innovation sought to be introduced into the pathology of rheumatism. He thought the term " muscular rheumatism" was very appropriately applied to the pains so often felt in the muscles after exposure to cold and wet. In his opinion the seat of such pains was in the muscular fibres, and the appellation " neuralgia" decidedly improper.

Dr. Olliffe defied the preceding speakers to point out a single anatomico-pathological appearance in muscular structure indicating inflammation, after the manifestation of the symptoms alluded to. He maintained that in almost all instances the seat of the pain sufficed to trace the anatomical course of the nerves; that in no case was there inflammation in "muscular rheumatism," which constantly exbibited the chronic type.

Mr. H. BENNET readily admitted that in many instances neuralgia existed when muscular rheumatism was diagnosed, but he could not allow that this was generally the case. He thought that the aponeuroses inclosing and separating the muscles, were frequently the seat of the inflammation in cases described as cases of muscular rheumatism. In rheumatism the pains felt in the continuity of the limbs, generally presented the same migratory character as the articular inflammations.

Dr. Ollifee again asserted the correctness of his views with regard to the nature of the so called " muscular rheumatism," views which were based on the absence of any lesions furnished by pathological anatomy calculated to prove the existence of a muscular affection. The disease commonly called muscular rheumatism was essentially different from simple inflammation of the muscular fibre, or hyolitis, which was of very rare occurrence.

\section{MEDICAL STUDIES AT BRUSSELS.}

To the Editor.-Sir: Devoted as is that estimable journal, THE LANCET, to the interests of the rising medical generation, I should express in its columns my surprise that no English students of medicine find their way to Brussels, were there not a probable reason supplied in the fact that they must be unacquainted with the advantages there offered to them; yet at Brussels we have a large, handsome, airy city, with a climate not unlike that of England, excepting that it is superior in dryness, and that fogs are less frequent and less dense in the former. Living is very cheap here, for although the market prices are but little below the smaller towns of Great Britain, yet competition, and the affluence of strangers, have an immense influence upon the amounts for which articles can be bought in Brussels. Decent board and lodging may be obtained by students for $3 l$. a month, and $4 l$. will effect the object handsomely and comfortably. The medical school, forming part of the university, has been established since 1836. The students in it are few, the opportunities numerous. There are two civil hospitals and one military, containing together upwards of eight hundred beds. Excellent lectures on chemistry, botany, mine. ralogy, comparative and human anatomy, physiology, surgery, and the practice of medicine, are daily given during ten months of the year, and there is a liberal supply of subjects. All the consequent advantages of these things are obtainable for the annual charge of $8 l .10 \mathrm{~s}$, without extras. The chemical professor, M. Koene, is as skilful as he is indefatigable. Gluge is known as a physiologist to all Europe, and Seutin has recently been demonstrating his system of bandaging in the London hospitals. There are many other teachers in the university on whom I could bestow well-merited praise. In a word, in all branches, except practical medicine, much may be learned; and even in that, the do-nothing system on the one hand, and bleeding and gum-water on the other, may be watched in their effects, whilst pathological anatomy and auscultation are pursued with advantage. As to relaxation, since the bow of science cannot always be strung, pleasant walks and rides in summer; in winter, coffee-houses and clubs of a superior description, and an excellent theatre, afford varied and innocent recreation, on the most moderate terms. The pit of the opera, which may be named immediately after that of Paris or London, costs 1s. 4d., and students are admitted on still lower terms.

The chief impediment is unacquaintance with the French language, which a few months of practice may overcome, whilst the acquaintance with foreign men and manners has a humanising effect upon the mind, which all wise persons have appreciated from the days of Homer to our own. I remain, Sir, your admiring reader,

$$
\text { John Perkins, M.D., M.R.C.S.L. }
$$

Brussels, Dec. 20, 1842. 